\title{
Carpathian Journal of Mathematics celebrates 30 years of publication
}

\section{VASILE BERINDE}

\section{ABSTRACT.}

Following a well established tradition of marking the main anniversary moments of the journal by an editorial, see the previous ones: [Berinde, V., Anniversary: Ten years of publication of the new series of Buletin Ştiinţific, Bul. Ştiinţ. Univ. Baia Mare, Ser. B., Matematică-Informatică, 16 (2000), No. 1, i-ii], [Berinde, V., Carpathian Journal of Mathematics: Celebrating 20 years of publication of the new series, Carpathian J. Math., 21 (2010), No. 2, i-vi], [Berinde, V., CJM celebrates 25 years of publication of its new series, Carpathian J. Math., 26 (2015), No. 3, $\mathrm{i}-\mathrm{vi}]$, it is the main aim of this note to present a brief account of what has been achieved since the previous anniversary editorial written five years ago.

\section{REFERENCES}

[1] Berinde, V., Anniversary: Ten years of publication of the new series of Buletin Ştiinţific, Bul. Ştiinţ. Univ. Baia Mare, Ser. B., Matematică-Informatică, 16 (2000), No. 1, i-ii

[2] Berinde, V., Carpathian Journal of Mathematics: Celebrating 20 years of publication of the new series, Carpathian J. Math., 26 (2010), No. 2, i-vi

[3] Berinde, V., CJM celebrates 25 years of publication of its new series, Carpathian J. Math., 26 (2015), No. 3, i-vi

${ }^{1}$ Department of Mathematics And COMPUter SCIENCE

NORTH UNIVERSITY CENTER AT BAIA MARE

TECHNICAL UNIVERSITY OF CLUJ-NAPOCA

VictorieI 76, 430122 BAIA MARE, ROMANIA

${ }^{2}$ ACADEMY OF ROMANIAN SCIENTISTS

Email address: vberinde@cunbm.utcluj.ro

Email address: vasile.berinde@gmail.com

Received: 15.08.2020; In revised form: 15.08.202020; Accepted: 23.08.2020

2010 Mathematics Subject Classification. 01A99.

Key words and phrases. journal publication: anniversary. 